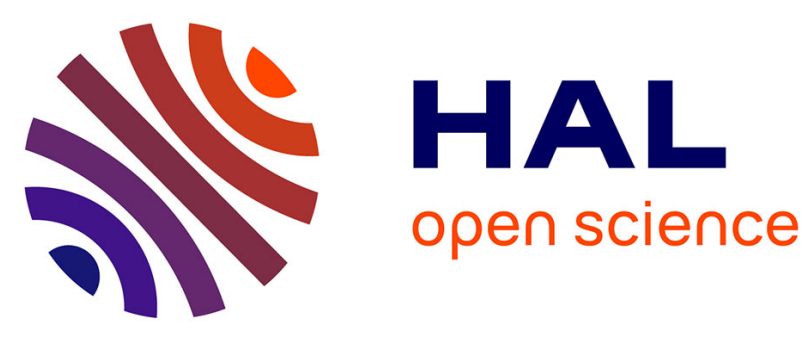

\title{
Molecular tectonics: silver coordination networks based on tetramercaptothiacalix[4] arene in 1,3-alternate conformation bearing four nitrile groups
}

Alexander Ovsyannikov, Sylvie Ferlay, Svetlana Solovieva, Igor Antipin, A. Konovalov, Nathalie Kyritsakas, Mir Wais Hosseini

\section{To cite this version:}

Alexander Ovsyannikov, Sylvie Ferlay, Svetlana Solovieva, Igor Antipin, A. Konovalov, et al.. Molecular tectonics: silver coordination networks based on tetramercaptothiacalix[4]arene in 1,3-alternate conformation bearing four nitrile groups. Russian Chemical Bulletin, 2015, 64 (8), pp.1955-1962. 10.1007/s11172-015-1099-8 . hal-02301069

\section{HAL Id: hal-02301069 \\ https://hal.science/hal-02301069}

Submitted on 25 Nov 2020

HAL is a multi-disciplinary open access archive for the deposit and dissemination of scientific research documents, whether they are published or not. The documents may come from teaching and research institutions in France or abroad, or from public or private research centers.
L'archive ouverte pluridisciplinaire HAL, est destinée au dépôt et à la diffusion de documents scientifiques de niveau recherche, publiés ou non, émanant des établissements d'enseignement et de recherche français ou étrangers, des laboratoires publics ou privés. 
Molecular tectonics: silver coordination networks based on tetramercaptotetrathiacalix[4]arene in 1,3-A conformation bearing four nitrile groups

\author{
A.S. Ovsyannikov, ${ }^{a, b}$ S. Ferlay, ${ }^{* b}$ S. E. Solovieva, ${ }^{a}$ I. S. Antipin, ${ }^{* a, c}$ A. I. Konovalov ${ }^{a, c}, N$. \\ Kyritsakas, ${ }^{b}$ M. W. Hosseini ${ }^{* b}$ \\ ${ }^{a}$ A.E. Arbuzov Institute of Organic and Physical Chemistry of Russian Academy of Science, \\ Arbuzov st.8, 420088, Kazan, Russian Federation \\ ${ }^{b}$ Université de Strasbourg, Laboratoire de Tectonique Moléculaire, UMR-CNRS 7140, Institut \\ Le Bel, 4 rue Blaise Pascal, 67070 Strasbourg, France \\ ${ }^{c}$ Kazan Federal University, Kremlyovskaya st. 18,420008, Kazan, Russian Federation \\ E-mail: osaalex2007@rambler.ru
}

Two tetrasubsituted derivatives of tetramercaptothiacalix[4]arene in 1,3-alternate conformation bearing either four (3-cyano)propyl (2) or (4-cyano)benzyl (3) moieties have been synthesized and characterized in solution as well as in the solid state by X-ray diffraction on single crystals. Their propensity to form coordination networks was investigated in the presence of silver cation as connecting metal and hexafluorophosphate as counter ion. Whereas the combination of $\mathrm{AgPF}_{6}$ and $\mathbf{2}$ bearing four (3-cyano)propyl groups leads to a $1 \mathrm{D}$ silver coordination network, for $\mathbf{3}$, containing four (4-cyano)benzyl units, a 3D diamond-like architecture is obtained.

Key words: tetramercaptothiacalix[4]arene, molecular tectonics, coordination polymer, Silver, nitrile.

\title{
Introduction
}

Coordination Polymers (CPs)' or coordination networks² ${ }^{2}$ are extended periodic architectures generated upon mutual bridging between organic tectons and metal centres or metal 
complexes under self-assembly processes. Since the pioneer work of Robson,' this class of crystalline materials has been extensively studied. ${ }^{3}$ Beside exploring the formation of new periodic networks in the solid state, the development of this area arises from applicative issues for example in catalysis, separation and storage or tailored physical properties such as electronic, optic, magnetism, conduction etc, resulting from precise positioning of molecular components composing the crystal in periodic architectures. The design of coordination networks remains still challenging and requires the control of several parameters involved in the self-assembly processes. ${ }^{4}$ For some time now, we explore the molecular tectonics approach, ${ }^{5,6}$ which deals with the design and formation of molecular networks and in particular coordination polymers in the crystalline phase. For molecular tectonics applied to coordination networks, mainly, two strategies may be explored. The first one deals with precisely designed organic tectons with restricted conformational space, usually based on rigid backbones, defined coordinating sites (nature, number and location) and properly chosen metal centres with preferred coordination geometry or metal complexes offering predefined free coordination sites. The second approach, much more exploratory, may be based on combinations of flexible organic polydentate tectons offering a rather large number of coordinating sites and metal centres with or without specific coordination requirements (geometry, coordination number, size etc). In that case, owing to the rather large spatial possibility, the construction strategy can not be directed and thus no prediction may be made. However, this strategy might have its own merit since it may lead to complex architectures which could be of interest in terms of connectivity (structural novelty) and/or application.

Calix[4]arene is an interesting backbone for the design of receptors, ligands and tectons.? Indeed, this cyclic molecule offers four phenolic units and, owing to its non planar nature due to steric hindrance, four limit conformations (cone $(C)$, partial cone $(C P), 1,2$-Alternate and 1,3-Alternate) are observed. Among these four conformers, the 1,3-Alternate one is particularly well suited for the formation of infinite networks. The calix[4]arene backbone 
may be equipped with peripheral coordinating sites and thus may be used for the formation of coordination networks in the crystalline phase. For example, an infinite 1D coordination network has been generated upon combining the blocked 1,3-Alternate conformer of a calix[4]arene derivative bearing four $\mathrm{CN}$ groups at the upper rim with silver cation. Thiacalix[4]arene (TCA) is an analogue of calix[4]arene for which all four $\mathrm{CH}_{2}$ groups connecting the phenol moieties are replaced by $S$ atoms. As for calix[4]arene, thiacalix[4]arene also offers four conformations in solution..$^{10}$ Owing to the presence of four $\mathrm{S}$ atoms, the main difference between calix[4]arene and thiacalix[4]arene resides in the propensity of thiacalix[4]arene to bind thiophilic metal centres." The formation of periodic infinite 1-, 2- and 3-D silver coordination networks using thiacalix[4]arene derivatives in 1,3-Alternate conformation bearing four nitrile groups ${ }^{12}$, carboxylate units $^{13}$, pyridyl units $^{14}$ or four benzonitrile groups ${ }^{15}$ has been reported by us. Another example of a 1D silver coordination network based on a thiacalix[4]arene bearing ether groups has also been reported ${ }^{16}$ More recently, the formation of periodic architectures resulting from combinations of thiacalix[4]arene derivatives in 1,3-Alternate conformation bearing carboxylate moieties, Co(II) salts and bispyridyl auxiliary ligands has been published. ${ }^{17}$

Within the thiacalix[4]arene family, tetramercaptotetrathiacalix[4]arene (TMTCA), an analogue of TCA for which all four $\mathrm{OH}$ moieties at the lower rim are replaced by $\mathrm{SH}$ groups,$^{18}$ is another interesting backbone for the design of organic tectons. Indeed, for the 1,3-Alternate conformer, all four $\mathrm{SH}$ groups may be functionalized by coordinating sites leading thus to tectons offering 12 potential coordinating sites. Recently, examples of coordination networks based on combinations of TMTCA appended with four pyridyl groups and $\mathrm{Hg}(\mathrm{II})$ cation have been reported by us. ${ }^{19}$

For exploring the second strategy based on non-directed generation of coordination networks discussed above, TMTCA based tectons bearing four peripheral nitrile sites is of particular interest (Figure 1). Indeed this type of ligands, as stated above, offers 12 coordinating sites 
with similar coordination propensity ( 8 thioether and four nitrile sites). However, in order to restrain the possibility space, only the 1,3-Alternate conformer was explored.

In this contribution, we report on the design, synthesis and structural characterisation of two TMTCA based organic tectons $\mathbf{2}$ and $\mathbf{3}$ (Scheme 1) bearing four cyanopropyl (2) or cyanobenzyl (3) coordinating groups and their combinations with $\mathrm{AgPF}_{6}$ silver salts. Tectons 2 and 3 differ by the nature of the spacer connecting the nitrile groups to the thiacalix backbone by thioether junctions.

\section{Results and discussion}

The starting material for the preparation of tectons $\mathbf{2}$ and $\mathbf{3}$ was the tetramercaptotetrathiacalix[4]arene 1 (TMTCA) prepared as previously described (Scheme 1). ${ }^{18}$ As for the thiacalix[4]arene cyanopropyl and cyanobenzyl appended analogues, ${ }^{12.15}$ compounds 2 and $\mathbf{3}$ have been obtained in 50 and $44 \%$ yield respectively, upon condensation under reflux of the parent calix derivative 1 with either 4-Chlorobutyronitrile or 4bromomethylbenzonitrile in dry acetone and in the presence of $\mathrm{Cs}_{2} \mathrm{CO}_{3}$. In both cases, only the 1,3-Alternate conformer was isolated (see experimental part). Both compounds $\mathbf{2}$ and $\mathbf{3}$ have been characterised in solution by NMR spectroscopy as well as in the solid state by Xray diffraction on single crystal. Crystals were obtained upon slow diffusion or evaporation of $\mathrm{MeOH}$ into a $\mathrm{CH}_{2} \mathrm{Cl}_{2}$ solution of either tecton $\mathbf{2}$ or $\mathbf{3}$ (see experimental part). The structural investigation confirmed the 1,3-Alternate conformation for both compounds (see crystallographic table 2). For both cases, the metrics (see table 1) for the macrocyclic part was found to be close to the one observed for the parent compound $\mathbf{1} .^{19}$

Whereas tecton 2 crystallises in the absence of solvent molecules $\left(\left\{\mathrm{C}_{56} \mathrm{H}_{68} \mathrm{~N}_{4} \mathrm{~S}_{8}\right\}\right)$, crystals of 3 contain $\mathrm{CH}_{2} \mathrm{Cl}_{2}$ solvent molecules $\left(\left\{2\left(\mathrm{C}_{72} \mathrm{H}_{68} \mathrm{~N}_{4} \mathrm{~S}_{8}\right) \mathrm{CH}_{2} \mathrm{Cl}_{2}\right\}\right)$. In the crystalline phase, compound 2 adopts a rather symmetrical arrangement (space group I4/a, see crystallographic table 2 ) 
with three $\mathrm{C}_{2}$-axis. All four pendant 3-cyanopropyl groups, located alternatively above and bellow the main plane of the macrocycle, are outwardly orientated (figure 2).

Compound 3 crystallises in the triclinic $P-1$ space group (see crystallographic table 2 ). The $\mathrm{CH}_{2} \mathrm{Cl}_{2}$ solvent molecules occupy the interstice between the calixarene moieties. No specific interactions between the solvent molecules and the calix units are spotted in the crystal. The four cyanobenzyl groups are orientated along the axis perpendicular to the main plane defined by the four S atoms connecting the aryl groups (figures 3). One of the four tert-butyl groups as well as three of the phenyl groups of the cyanobenzyl moieties were found to be disordered.

For the formation of coordination networks, tectons $\mathbf{2}$ and $\mathbf{3}$ were combined with $\mathrm{Ag}^{+}$cation. Since compounds $\mathbf{2}$ and $\mathbf{3}$ are neutral tectons, the weakly coordinating $\mathrm{PF}_{6}$ anion was used as the counter ion. The choice of $\mathrm{Ag}^{+}$cation was based on its $\mathrm{d}^{10}$ electronic configuration and thus is rather loose coordination demands.

The silver coordination network $2-\mathrm{AgPF}_{6}$ was obtained upon slow evaporation at $25^{\circ} \mathrm{C}$ of a solution containing the organic tecton 2 and $\mathrm{AgPF}_{6}$ in a $\mathrm{CHCl}_{3}$ and $\mathrm{CH}_{3} \mathrm{OH} 1 / 1$ mixture. Crystals composed 3- $\mathrm{AgPF}_{6}$ networks were obtained upon slow diffusion of a $\mathrm{CH}_{3} \mathrm{OH}$ solution containing $\mathrm{AgPF}_{6}$ tecton 3 through a $\mathrm{CHCl}_{3} /$ iso-PrOH buffer (see experimental part). Both crystals were studied by X-ray diffraction methods on single crystals and on powder. The structural results obtained are discussed bellow. However, owing to similarities observed for bond distances for the calix framework when compared to free tectons in $\mathbf{2}$ and $\mathbf{3}$, they will not be discussed here.

Compound 2- $\mathrm{AgPF}_{6}$ crystallises in the $\mathrm{P} 2(1) / n$ space group. The crystal is only composed of the organic tecton 2 and $\operatorname{AgPF}_{6}$ salt $\left\{\left(\mathrm{C}_{56} \mathrm{H}_{68} \mathrm{~N}_{4} \mathrm{~S}_{8}\right) \mathrm{AgP} \mathrm{F}_{6}\right\}$. The metal/tecton ratio is $1 / 1$. The crystal is formed by packing of extended 1D periodic silver coordination networks. 
The formation of the 1D architecture results from interconnection of consecutive calix based mononuclear silver complexes $\mathbf{2}-\mathrm{Ag}^{+}$by a single nitrile group belonging to consecutive silver complexes through $\mathrm{N}-\mathrm{Ag}$ bonds with $\mathrm{d}_{\mathrm{Ag} \mathrm{N} \text { II }}$ of $\left.2.280(5) \AA\right)$. Only one out of the four cyanopropyl groups of the calix backbone takes place in the connectivity pattern (figure 4). The $\mathrm{PF}_{6}$ anions are located in the interstices with no specific interactions with the network. The silver cation, located within the cavity of the macrocyclic backbone, adopts a deformed triangular coordination geometry (figure 5). It is surrounded by two $\mathrm{S}$ atoms of the $\mathrm{Ph}-\mathrm{S}-\mathrm{CH}_{2}$ with Ag-S distance of 2.511(4) $\AA$ and 2.4575(15) $\AA$ ) and one $\mathrm{N}$ atom belonging to the cyanopropyl unit of the consecutive silver complex with Ag-N distance of 2.280(5) $\AA$ ). One of the four propyl groups of $\mathbf{2}$ was found to be disordered.

The 1D network is acentric and thus directional. However, the crystal is centric. This results from the syn-parallel packing of the directional 1D networks within the [101] direction leading to a polar 2D arrangement (figure 6). Consecutive planes are packed in an antiparallel mode in the $(1,0,0)$ plane leading thus to a non polar crystal (figure 7 ).

The observed 1D network is different from the one formed using the TCA analogue for which no Ag-S bond is present. ${ }^{12}$

The homogeneity of the polycrystalline powder of $2-\mathrm{AgPF}_{6}$ has been checked by XRPD (figure 8) which revealed the presence of a single monoclinic phase consistent with the simulated pattern from the XRD data obtained on single crystal.

Compound 3- $\mathrm{AgPF}_{6}$ crystallises also in the $\mathrm{P} 2(1) / \mathrm{n}$ space group. The crystal $\left(\left\{\left(\mathrm{C}_{22} \mathrm{H}_{68} \mathrm{~N}_{4} \mathrm{~S}_{8}\right)_{4}\left(\mathrm{AgPF}_{6}\right)_{8}\left(\mathrm{CH}_{3} \mathrm{OH}\right) 4 \mathrm{CH}_{3} \mathrm{OH} 2 \mathrm{CHCl}_{3}\right\}\right)$ in addition to 3 and $\mathrm{AgPF} 6$ contains $\mathrm{MeOH}$ and $\mathrm{CHCl}_{3}$ solvent molecules. The metal/ligand ratio is $2 / 1$. The $\mathrm{X}$-ray diffraction method revealed the formation of a diamond type 3D silver coordination network. The latter results from interconnection of consecutive organic tectons $\mathbf{3}$ acting as tetrahedral connectors, by silver cations adopting a deformed triangular coordination geometry but behaving as a linear 
connector (figure 9a and 9b). Two types of crystallographically non equivalent silver cations are present in the network. The first one is surrounded by two $\mathrm{N}$ atoms of two nitrile coordinating groups belonging to two consecutive tectons 3 with Ag-N distances of 2.297(8) and 2.319(7) $\AA$ and by one sulphur atoms belonging to the sulphur bridge of the TMTCA backbone with Ag-S distances of $2.5448(17) \AA$. The metal cation adopts a deformed triangular coordination geometry with $\mathrm{NAgN}$ angle of $95.2(3)^{\circ}$, and $\mathrm{NAgS}$ angles of 115.8(19) and $132.4(2)^{\circ}$. The other silver atom is surrounded by one $\mathrm{N}$ atom of a nitrile moiety, one oxygen belonging to a coordinated $\mathrm{MeOH}$ molecule and one sulphur atoms belonging to the sulphur bridge of TMTCA with Ag-N, Ag-O distances of 2.214(8), 2.380(10) A respectively and Ag-S distance of 2.5111(18). Again, the trigonal environment of the silver cation is strongly deformed with $\mathrm{NAgO}$ angle of $106.4(3)^{\circ}, \mathrm{OAgS}$ angle of $112.7(3)^{\circ}$ and NAgS angle of $140.7(2)^{\circ}$. For the organic tecton 2 , two disordered tert-butyl groups are observed.

The structure is non porous since uncoordinated cyanobenzyl groups, $\mathrm{PF}_{6}{ }^{-}$anions and non coordinated $\mathrm{MeOH}$ solvent molecules occupy the cavities of the 3D diamandoid architecture. Crystals of $3-\mathrm{AgPF}_{6}$ are not stable in air (loss of solvent molecules). Consequently, the homogeneity of the polycrystalline powder could not be established by PXRD.

\section{Conclusion}

Tetrasubstituted TMTCA in 1,3-alternate conformation bearing four (3-cyano)propyl (2) or (4-cyano)benzyl (3) groups at the lower rim behave as organic coordinating tectons. Their combination with $\mathrm{AgPF}_{6}$ salt leads to $1 \mathrm{D}$ and $3 \mathrm{D}$ coordination polymers respectively with participation of nitrile and thioether groups in the connectivity pattern. Although it appears that the dimensionality of the network depends on the rigidity of the organic tectons ( 2 is less rigid than 3), owing to the high number of possible coordinating centres (4N and $8 \mathrm{~S}$ ), it was not possible to predict the connectivity and thus the dimensionality of the networks.

\section{Experimental part}


'H NMR spectra were recorded at room temperature on a Bruker (300 $\mathrm{MHz}) \mathrm{NMR}$ spectrometer.

FT-IR spectra were recorded on a Perkin Elmer spectrometer.

Mass spectra $(\mathrm{MS}(\mathrm{ES}+))$ were obtained on a MALDI-TOF Dynamo Finnigan mass spectrometer using 1,8,9-Trihydroxyanthracene or p-nitroaniline as matrix.

Microanalyses were performed by the Service de Microanalyses de la Fédération de Recherche Chimie, Université de Strasbourg, Strasbourg, France.

X-ray diffraction on Single-Crystal. Data were collected at 173(2) K on a Bruker APEX8 CCD Diffractometer equipped with an Oxford Cryosystem liquid $\mathrm{N}_{2}$ device, using graphitemonochromated Mo-K $\alpha(\lambda=0.71073 \AA)$ radiation. For both structures, diffraction data were corrected for absorption. Structures were solved using SHELXS-97 and refined by full matrix least-squares on $F^{2}$ using SHELXL-97. The hydrogen atoms were introduced at calculated positions and not refined (riding model). ${ }^{20}$ They can be obtained free of charge from the Cambridge Crystallographic Data Centre via www.ccdc.cam.ac.uk/datarequest/cif. CCDC: $1034868-1034871$.

X-ray Diffraction on microcrystalline powder. Powder X-ray diffraction (PXRD) diagrams were collected for $\mathbf{2}-\mathbf{A g P F}_{\mathbf{6}}$ and $\mathbf{3}-\mathbf{A g P F}_{\mathbf{6}}$ on a Bruker D8 diffractometer using monochromatic $\mathrm{Cu}-\mathrm{K} \alpha$ radiation with a scanning range between 3.8 and $40^{\circ}$ using a scan step size of $2 \% \mathrm{mn}$.

As already demonstrated and currently admitted, for all compounds, discrepancies in intensity between the observed and simulated patterns are due to preferential orientations of the microcrystalline powders.

25,26,27,28-tetrakis[(3-cianopropyl)thio]-5,11,17,23-tetra-tert-butyl-2,8,14,20tetrathiacalix[4]arene (1,3-Alternate conformation) (2). Under argon, a mixture of TMTCA $1(0.4 \mathrm{~g}, 0.51 \mathrm{mmol})$ and $\mathrm{Cs}_{2} \mathrm{CO}_{3}(3.33 \mathrm{~g}, 10.2 \mathrm{mmol})$ in dry and degassed acetone $(60 \mathrm{ml})$ was refluxed for 2 hours. $\mathrm{Cl}\left(\mathrm{CH}_{2}\right)_{3} \mathrm{CN}(0.9 \mathrm{ml}, 10.2 \mathrm{mmol})$ and a catalytic amount of $\mathrm{KI}$ were 
then added. The reaction mixture was refluxed 24 hours under argon. After cooling, the solid was filtered. The filtrate was evaporated. Methanol $(50 \mathrm{ml})$ was added to the residue. The precipitate was filtered and washed with ether $(20 \mathrm{ml})$ affording the desired compound $\mathbf{2}$ as a white powder $(0.26 \mathrm{~g}, 50 \%$ yield $)$. 'H-NMR $\left(\mathrm{CDCl}_{3}, 295 \mathrm{~K}\right) \delta(\mathrm{ppm}): 1.28(36 \mathrm{H}, \mathrm{s}, t \mathrm{Bu})$, $1.66\left(8 \mathrm{H}, \mathrm{m},-\mathrm{CH}_{2}-\right), 2.71\left(8 \mathrm{H}, \mathrm{t},-\mathrm{CH}_{2} \mathrm{CN}\right), 3.05\left(8 \mathrm{H}, \mathrm{t},-\mathrm{ArSCH}_{2}-\right), 7.67(8 \mathrm{H}, \mathrm{s}, \mathrm{Ar}-\mathrm{H})$; ${ }^{13} \mathrm{C}-$ $\operatorname{NMR}\left(\mathrm{CDCl}_{3}, 295 \mathrm{~K}\right) \delta(\mathrm{ppm}): 16.6,25.2,31.2,33.7,34.8,119.8,133.7,138.0,142.7,151.3$; MS(MALDI-TOF): m/z: $1075.3[\mathrm{M}+\mathrm{Na}]^{+}\left(\right.$calcd. 1076.69); FTIR: $v(\mathrm{C} \equiv \mathrm{N})=2245 \mathrm{~cm}^{-1}$; Anal. Calcd. for $\mathrm{C}_{56} \mathrm{H}_{68} \mathrm{~N}_{4} \mathrm{~S}_{8}$ : C, 63.83; H, 6.50, N, 5.32\% ; Found: C, 63.67; H, 6.49; N, 5.35\% ; Mp $\left({ }^{\circ} \mathrm{C}\right)=310$ (decomp.)

\section{5,26,27,28-tetrakis[(4-cyanobenzyl)thio]-5,11,17,23-tetra-tert-butyl-2,8,14,20-}

tetrathiacalix[4]arene (1,3-Alternate conformation) (3). Under argon, a mixture of TMTCA 1 $(0.25 \mathrm{~g}, 0.32 \mathrm{mmol})$ and $\mathrm{Cs}_{2} \mathrm{CO}_{3}(2.08 \mathrm{~g}, 6.4 \mathrm{mmol})$ in dry and degassed acetone $(60 \mathrm{ml})$ was refluxing 2 hours. 4-bromomethylbenzonitrile $(1 \mathrm{~g}, 5.12 \mathrm{mmol})$ and a catalytic amount of KI were then added. The reaction mixture was refluxed 48 hours under argon. After cooling, the solid was filtered. The filtrate was evaporated and treated with $2 \mathrm{M} \mathrm{HCl}(50 \mathrm{ml})$. The aqueous solution was extracted by $\mathrm{CHCl}_{3}(50 \mathrm{ml})$. The organic layer was separated, washed with water (50 ml), dried over $\mathrm{MgSO}_{4}$ and evaporated. The desired compound 3 (0.2 g, 44\% yield) was precipitated as a white solid from a $\mathrm{CHCl}_{3}-\mathrm{Et}_{2} \mathrm{O}$ mixture $(1 / 10,50 \mathrm{ml}) .{ }^{1} \mathrm{H}-\mathrm{NMR}\left(\mathrm{CDCl}_{3}, 295 \mathrm{~K}\right)$ $\delta$ (ppm): $1.11\left(36 \mathrm{H}, \mathrm{s}, t\right.$-Bu), $4.03\left(8 \mathrm{H}, \mathrm{s}, \mathrm{ArSCH}_{2}\right), 7.24$ (8H, d, Ar-H), 7.49 (8H, d, Ar-H), 7.56 $(8 \mathrm{H}, \mathrm{s}, \mathrm{Ar}-\mathrm{H}) ;{ }^{13} \mathrm{C}-\mathrm{NMR}\left(\mathrm{CDCl}_{3}, 295 \mathrm{~K}\right) \delta$ (ppm): 31.0, 34.7, 40.3, 110.9, 119.2, 130.0, 132.2,

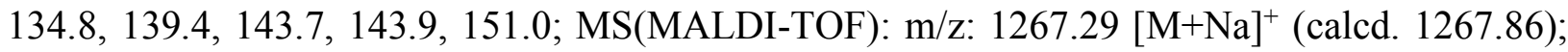
FTIR: $v(\mathrm{C} \equiv \mathrm{N})=2228 \mathrm{~cm}^{-1}$; Anal. Calcd. for $\mathrm{C}_{72} \mathrm{H}_{68} \mathrm{~N}_{4} \mathrm{~S}_{8}: \mathrm{C}, 69.41 ; \mathrm{H}, 5.50 ; \mathrm{N}, 4.50 \%$. Found: C, 69.25; H, 5.79; N, 4.42\%; Mp $\left({ }^{0} \mathrm{C}\right)=280$ (decomp.)

\section{Crystallisation conditions}


2: $2.0 \mathrm{ml}$ of methanol was added to a solution of $2(5 \mathrm{mg}, 0.0047 \mathrm{mmol})$ in $\mathrm{CH}_{2} \mathrm{Cl}_{2}(2.0$ $\mathrm{ml}$ ). Slow evaporation at room temperature produced colourless crystals suitable for X-ray diffraction after several days.

3: $2.0 \mathrm{ml}$ of methanol was added to a solution of $3(5 \mathrm{mg}, 0.0041 \mathrm{mmol})$ in $\mathrm{CH}_{2} \mathrm{Cl}_{2}(2.0$ $\mathrm{ml}$ ). Slow evaporation at room temperature produced colourless crystals suitable for X-ray diffraction after one day.

2-AgPF 6 : A solution of $2(5 \mathrm{mg}, 0.0047 \mathrm{mmol})$ in $\mathrm{CHCl}_{3}(2 \mathrm{ml})$ was mixed with a solution of $\mathrm{AgPF}_{6}(4.8 \mathrm{mg}, 0.0019 \mathrm{mmol})$ in $\mathrm{MeOH}(2 \mathrm{ml})$. Slow evaporation at the room temperature and in the dark produced after one day colourless crystals suitable for X-ray diffraction studies. Anal. Calcd. for $\operatorname{Ag}\left(\mathrm{C}_{56} \mathrm{H}_{68} \mathrm{~N}_{4} \mathrm{~S}_{8}\right) \mathrm{PF}_{6}$ : C, 51.45, H, 5.20, N, 4.28\%; Found: C, 49.95, H, 4.75, N, $3.80 \%$. FTIR: $v(\mathrm{C} \equiv \mathrm{N})=2247 \mathrm{~cm}^{-1}$.

3-AgPF 6 : In a crystallization tube $(20 \times 4 \mathrm{~mm})$, a solution of $3(5 \mathrm{mg}, 0.0041 \mathrm{mmol})$ in $\mathrm{CHCl}_{3}(1 \mathrm{ml})$ was layered with a $\mathrm{CHCl}_{3} /$ iso-PrOH $(1 / 1)$ mixture $(1 \mathrm{ml})$. A solution of $\mathrm{AgPF}_{6}(20$ $\mathrm{mg}, 0.0082 \mathrm{mmol})$ in $\mathrm{MeOH}(1 \mathrm{ml})$ was carefully added. Slow diffusion at room temperature and in the dark produced after 2 month colourless crystals suitable for X-ray diffraction studies. Anal. Calcd. for $\mathrm{Ag}_{8}\left(\mathrm{C}_{72} \mathrm{H}_{68} \mathrm{~N}_{4} \mathrm{~S}_{8}\right)_{4}\left(\mathrm{PF}_{6}\right)_{8}, 5 \mathrm{CH}_{4} \mathrm{O}, 2 \mathrm{CHCl}_{3}: \mathrm{C}, 47.54, \mathrm{H}, 4.04, \mathrm{~N}, 2.98 \%$; Found: C, 47.65, H, 4.08, N, 2.97\%. FTIR: $v(\mathrm{C} \equiv \mathrm{N})=2229 \mathrm{~cm}^{-1}$.

\section{Acknowledgments}

We thank the Universite de Strasbourg, Institut Universitaire de France, International Centre for Frontier Research in Chemistry, CNRS, ARCUS Programme, and Région Alsace (Ph.D. fellowship to A.O.) for financial support.

\section{References}

1. (a) B. F. Abrahams, B. F. Hoskins, R. Robson, J. Am. Chem. Soc., 1991, 113, 3606; (b) S. R. Batten, R. Robson, Angew. Chem. Int. Ed., 1998, 37, 1460.

2. M. W. Hosseini, CrystEngComm., 2004, 6, 318. 
3. (a) A. J. Blake, N. R. Champness, P. Hubberstey, W.-S. Li, M. A. Withersby, M. Schröder, Coord. Chem. Rev.,1999, 193, 117; (b) B. Moulton, M. J. Zaworotko, Chem. Rev., 2001, 101, 1629; (c) M. Eddaoudi, D. B. Moler, H. Li, B. Chen, T.M. Reineke, M. O’Keeffe, O. M. Yaghi, Acc. Chem. Res., 2001, 34, 319; (d) C. Janiak, Dalton Trans., 2003, 2781; (e) L. Carlucci, G. Ciani, D. M. Proserpio, Coord. Chem. Rev., 2003, 246, 247; (f) S. Kitagawa, R. Kitaura,, S. Noro, Angew. Chem. Int. Ed., 2004, 43, 2334; (g) G. Férey, C. Mellot-Draznieks, C. Serre, F. Millange, Acc. Chem. Res., 2005, 38, 218; (h) D. Bradshaw, J. B. Claridge, E. J. Cussen, T. J. Prior, M. J. Rosseinsky, Acc. Chem. Res., 2005, 38, 273; (i) S. Kitagawa, K. Uemura, Chem. Soc. Rev. 2005, 34, 109; (j) D. Maspoch, D. Ruiz-Molina, J. Veciana, Chem. Soc. Rev. 2007, 36, 770; (k) J. R. Long, O. M. Yaghi, Chem. Soc. Rev., 2009, 38, 1213; (1) C. Janiak, J. L. Vieth, New J. Chem., 2010, 34, 2366; (m) Chem. Soc. Rev., 2009, 38, themed issue on metal-organic frameworks; (n) W. L. Leong, J. J. Vittal, Chem. Rev. 2011, 111, 688; (o) Chem. Rev., 2012, 112, Metal-Organic Frameworks special issue.

4. N. R. Champness, Dalton Trans, 2011, 40, 10311.

5. (a) M. Simard, D. Su, J. D. Wuest, J. Am. Chem. Soc., 1991, 113, 4696; (b) S. Mann, Nature, 1993, 365, 499; (c) J. D. Wuest, Chem. Commun., 2005, 5830. (d) M. W. Hosseini, Chem. Commun., 2005, 5825.

6. M. W. Hosseini, Acc. Chem. Res., 2005, 38, 313.

7. (a) C. D. Gutsche in Calixarenes Revised: Monographs in Supramolecular Chemistry Vol. 6, The Royal Society of Chemistry, Cambridge, 1998; (b) Z. Asfari, V. Böhmer, J. Harrowfield and J. Vicens in Calixarenes 2001, (Eds. Z. Asfari, V. Böhmer, J. Harrowfield and J. Vicens) Kluwer Academic, Dordrecht, 2001; (c) M. W. Hosseini, ACS Series, Eds G. J. Lumetta, R. D. Rogers, A. S. Gopalan, 2000, 557, 296.

8. G. Mislin, E. Graf, M. W. Hosseini, A. De Cian, N. Kyritsakas, J. Fischer, Chem Commun., $1998,2545$. 
9. H. Kumagai, M. Hasegawa, S. Miyanari, Y. Sugawa, Y. Sato, T. Hori, S. Ueda, H. Kamiyama and S. Miyano, Tetrahedron Lett., 1997, 38, 3971.

10. H. Akdas, L. Bringel, E. Graf, M. W. Hosseini, G. Mislin, J. Pansanel, A. De Cian, J. Fischer, Tetrahedron Lett., 1998, 39, 2311.

11. (a) M. W. Hosseini in Calixarenes 2001, (Eds. Z. Asfari, V. Böhmer, J. Harrowfield and J. Vicens) Kluwer Academic, Dordrecht, 2001, pp.110; (b) T. Kajiwara, N. Iki, M. Yamashita, Coord. Chem. Rev. 2007, 251, 1734.

12. M. N. Kozlova, S. Ferlay, S. E. Solovieva, I. S. Antipin, A. I. Konovalov, N. Kyritsakas, M. W. Hosseini, Dalton Trans., 2007, 5126.

13. H. Akdas, E. Graf, M. W. Hosseini, A. De Cian, J. M. Harrowfield, Chem. Commun., 2000, 2219.

14. (a) A. Ovsyannikov, M. N. Lang, S. Ferlay, S. E. Solovieva, I. S. Antipin, A. I. Konovalov, N. Kyritsakas, M. W. Hosseini, Dalton Trans., 2013, 42, 126; (b) A. Ovsyannikov, S. Ferlay, S. E. Solovieva, I. S. Antipin, A. I. Konovalov, N. Kyritsakas, M. W. Hosseini, Dalton Trans., 2013, 42, 9946.

15. M. N. K Kozlova, S. Ferlay, N. Kyritsakas, M. W. Hosseini, S. E. Solovieva, I. S. Antipin, A. I. Konovalov, Chem. Commun., 2009, 2514.

16. J. Sykora, M. Himl, I. Stobor, I. Cisarova, P. Lhotak, Tetrahedron, 2007, 63, 2244.

17. (a) K. Kim, S. Park, K-M. Park, S. S. Lee Cryst. Growth Des., 2011, 11, 4059; (b) S. P. Bew, A. D. Burrows, T. Duren, M. F. Mahon, P. Z. Moghadam, V. M. Sebestyen and S. Thurston, Chem. Commun., 2012, 48, 4824; (c) Z. Zhang, A. Drapailo, Y. Matvieiev, L. Wojtas and M. J. Zaworotko Chem. Commun., 2013, 49, 8353.

18. (a) P. Rao, M. W. Hosseini, A. De Cian, J. Fischer, Chem. Commun., 1999, 2169; (b) H. Akdas, E. Graf, M. W. Hosseini, A. de Cian, A. Bilyk, B. W. Skelton, G. A. Koutsantonis, I. Murray, J. M. Harrowfield, A. H. White, Chem. Commun., 2002, 1042. 
19. (a) A. Ovsyannikov, S. Ferlay, S. E. Solovieva, I. S. Antipin, A. I. Konovalov, N. Kyritsakas, M. W. Hosseini, Inorg. Chem., 2013, 52, 6776; (b) A. Ovsyannikov, S. Ferlay, S. E. Solovieva, I. S. Antipin, A. I. Konovalov, N. Kyritsakas, M. W. Hosseini, Dalton., 2014, 43, 158; (c) A. Ovsyannikov, S. Ferlay, S. E. Solovieva, I. S. Antipin, A. I. Konovalov, N. Kyritsakas, and Mir Wais Hosseini CrystEngComm, 2014, 16, 3765.

20. Sheldrick, G. M.: Program for Crystal Structure Solution; University of Göttingen: Göttingen, Germany, 1997. 


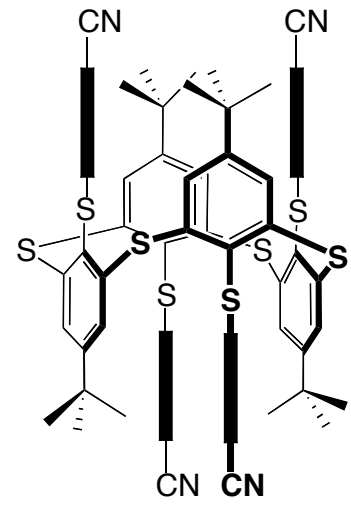

Figure 1. 


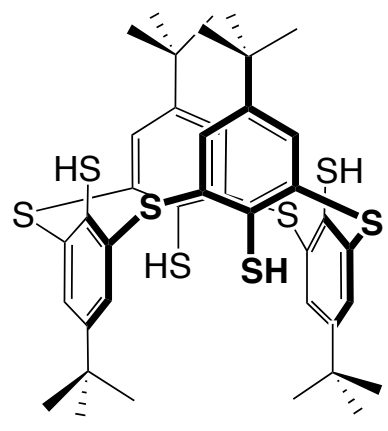

1

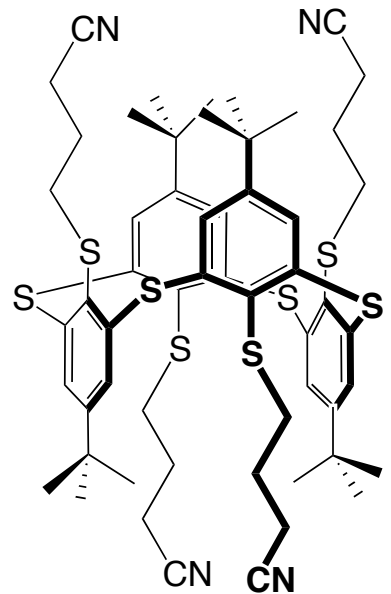

2

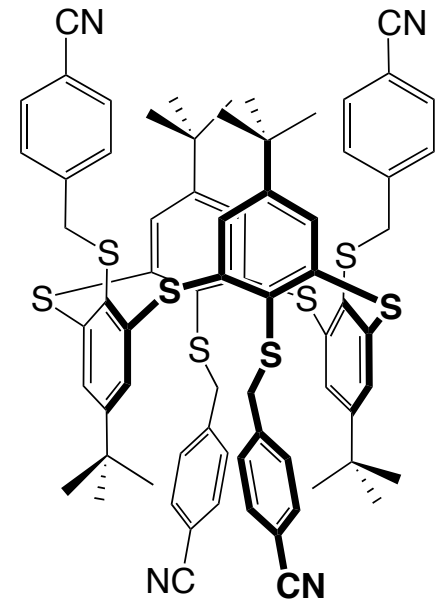

3

Scheme 1. 


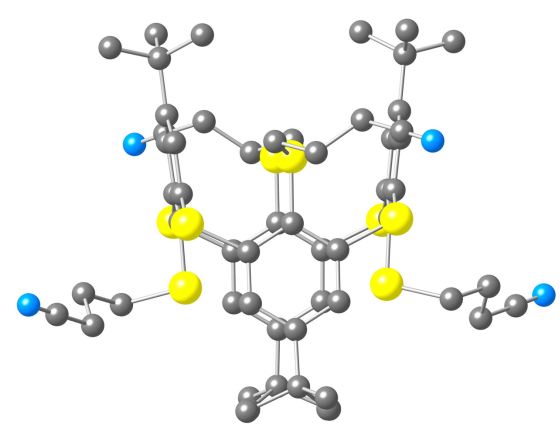

Figure 2. 


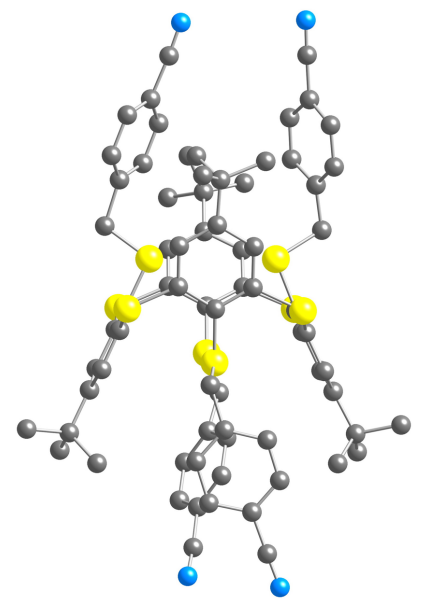

Figure 3. 


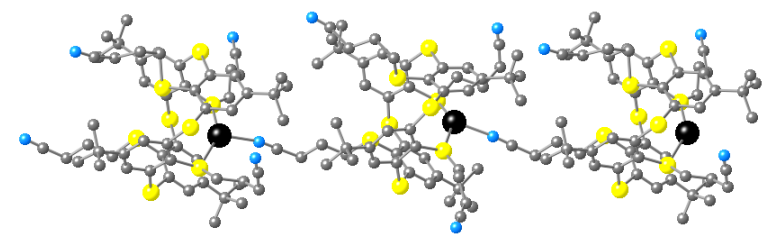

Figure 4. 


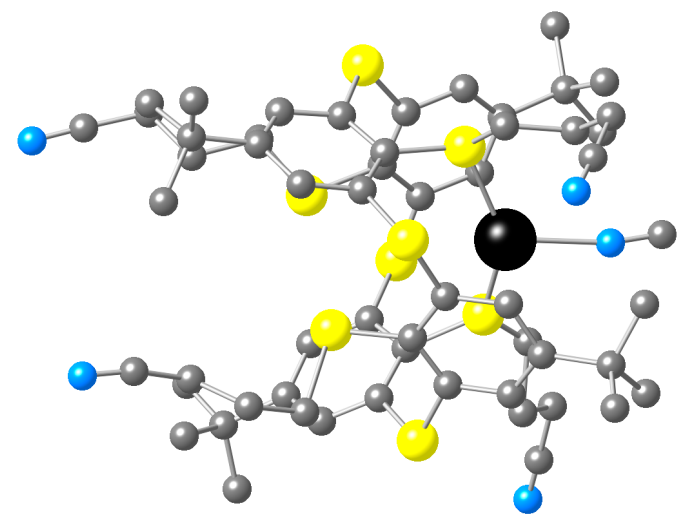

Figure 5. 


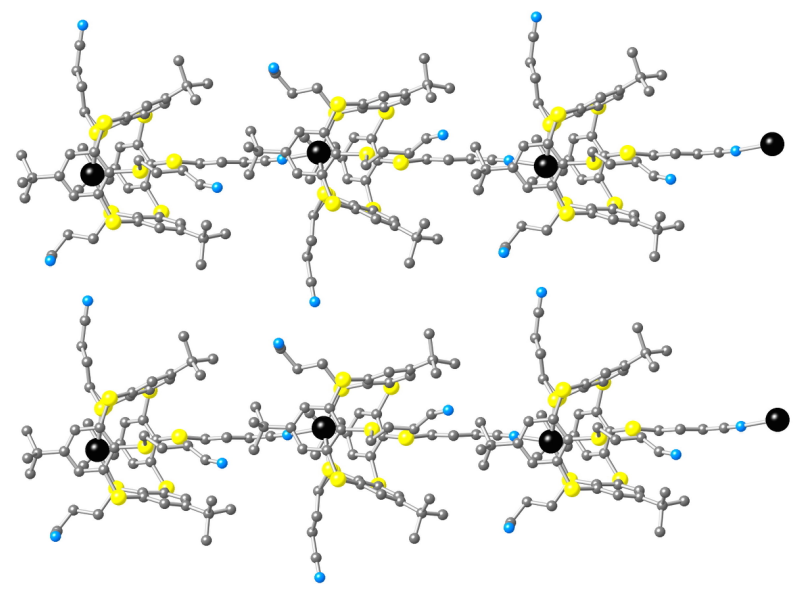

Figure 6. 


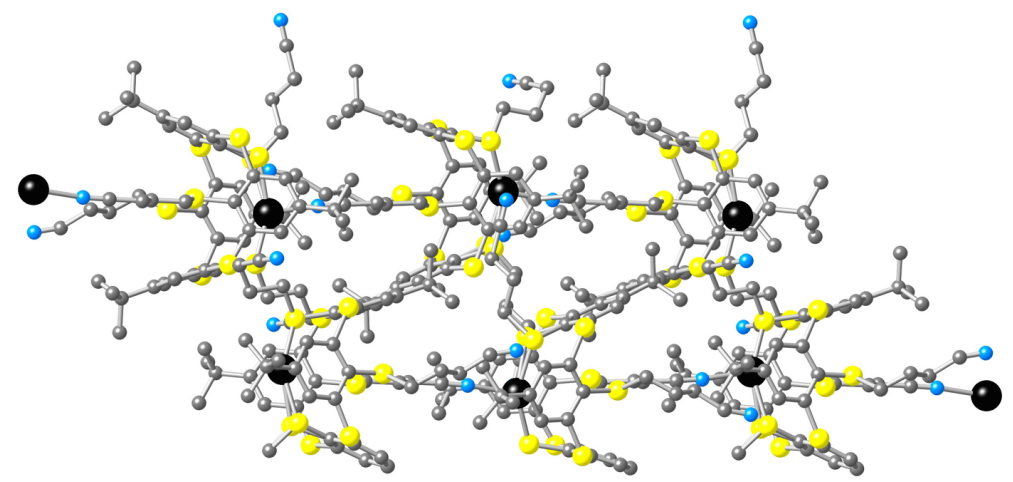

Figure 7. 


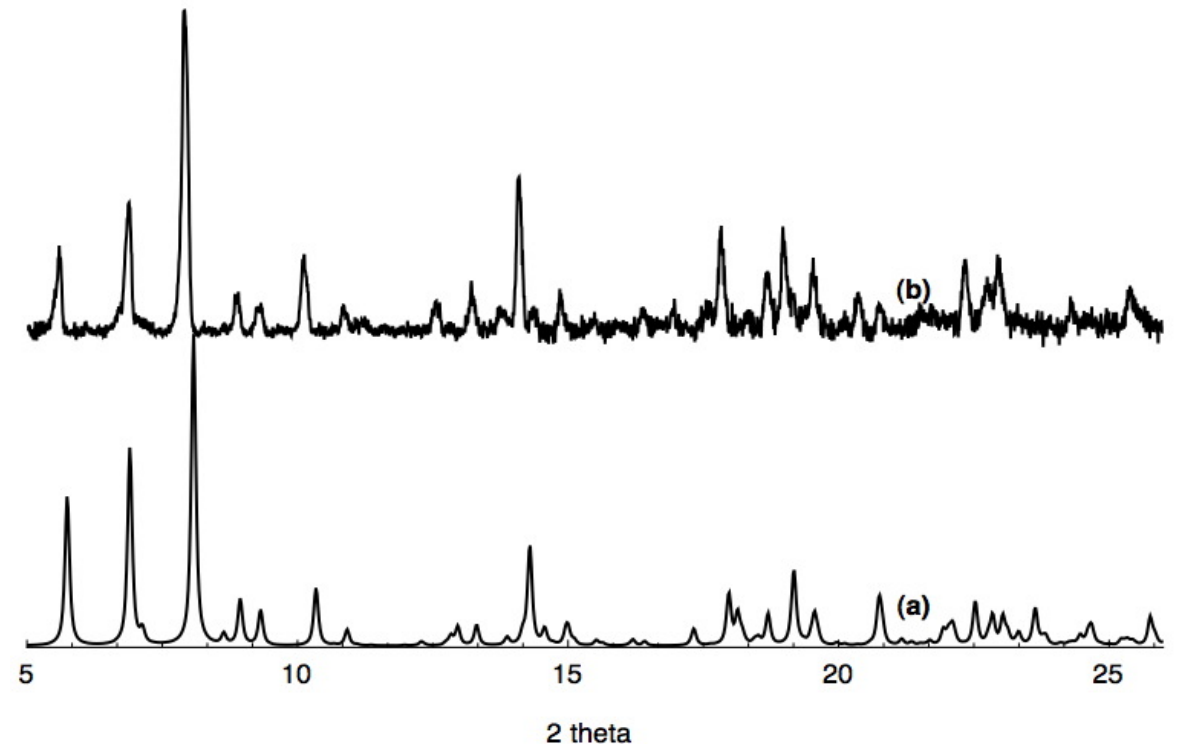

Figure 8. 


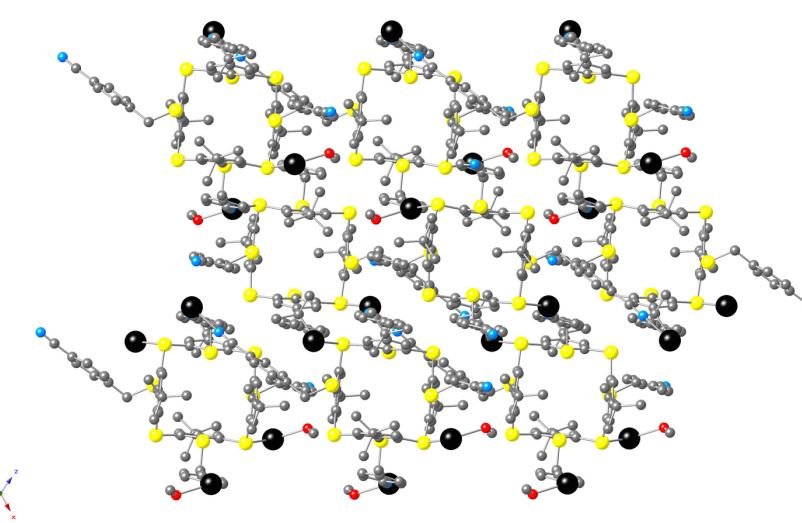

a

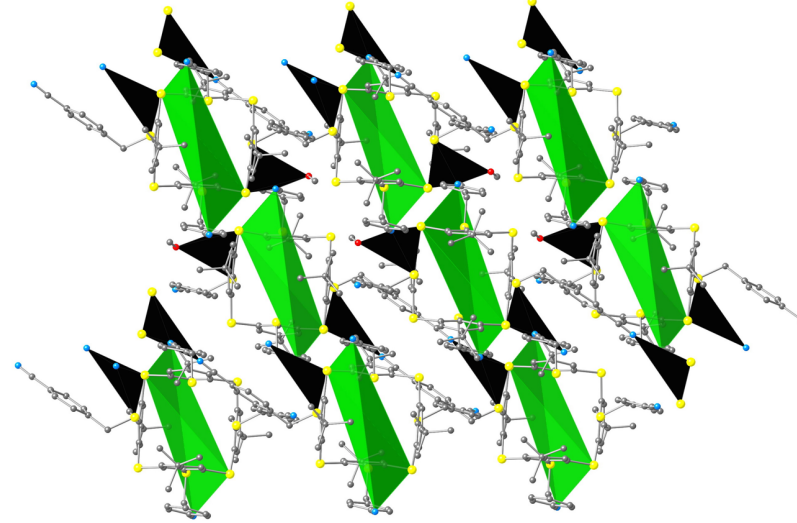

b

Figures 9. 
Figure 1. Schematic representation of tetramercaptotetrathiacalix[4]arene based tectons bearing four appended nitrile groups showing the 1,3-Alternate conformation and the localization of the 12 potential coordinating sites $\left(8 \mathrm{~S}\right.$ atoms of the $\mathrm{Ph}-\mathrm{S}-\mathrm{Ph}$ and $\mathrm{Ph}-\mathrm{S}-\mathrm{CH}_{2}$ types and four $\mathrm{CN}$ moieties, the black rectangle represents the spacer connecting the $\mathrm{S}$ atom to the $\mathrm{CN}$ group).

Scheme 1. Tectons based on the tetramercaptotetrathiacalix[4]arene (TMTCA, 1) backbone grafted with four cyanopropyl (2) or four cyanobenzyl (3) groups.

Figure 2. Solid-state structure of tecton 2 showing the 1,3-Alternate conformation adopted by the calix backbone and the orientation of the nitrile groups located above and bellow the main plane of the macrocycle. $\mathrm{H}$ atoms and solvent molecules are omitted for clarity.

Figure 3. Solid-state structure of tecton 3 showing the 1,3-Alternate conformation adopted by the calix backbone and the orientation of the nitrile groups located above and bellow the main plane of the macrocycle. $\mathrm{H}$ atoms and solvent molecules are omitted for clarity.

Figure 4. A portion of the $1 \mathrm{D}$ silver coordination network obtained upon combining the organic tecton 2 and $\mathrm{AgPF}_{6}$ salt. $\mathrm{H}$ atoms are omitted for clarity. For bond angles and distances see text.

Figure 5. A portion of the structure of 2-Ag showing the binding of $\mathrm{Ag}^{+}$cation and the surrounding of the later. $\mathrm{H}$ atoms are omitted for clarity. For bond angles and distances see text.

Figure 6. A portion of the structure of 2-Ag showing the syn-parallel packing of directional 1D networks in the [101] direction leading to a polar sheet. $\mathrm{H}$ atoms are omitted for clarity. For bond angles and distances see text.

Figure 7. A portion of the structure of 2-Ag showing the anti-parallel packing of consecutive directional sheets in the $(1,0,0)$ plane leading to a non polar crystal. $\mathrm{H}$ atoms are omitted for clarity. For bond angles and distances see text.

Figure 8. Comparison of the simulated (a) and recorded (b) PXRD patterns for 2-AgPF 6 showing the presence of a single phase. 
Figures 9. A view, in balls and sticks (a) and in polyhedral representations in the $(1,0,1)$ plane of a portion of the $3 \mathrm{D}$ crystal structure of $3-\mathrm{AgPF}_{6}$. Disordered and hydrogen atoms as well as solvent molecules are not represented for clarity. For the connectivity patterns, bond distances and angles see text. 
Table 1 : Useful angles and distances for $\mathbf{2}$ and $\mathbf{3}$

\begin{tabular}{|l|c|c|}
\hline & $\mathbf{2}$ & $\mathbf{3}$ \\
\hline $\mathrm{d}-\left(\mathrm{C}_{\mathrm{Ar}}-\mathrm{S}\right)(\AA)$ & $1.7818(17)$ & $1.768(7)-1.790(7)$ \\
\hline $\mathrm{d}-\left(\mathrm{C}_{\mathrm{Ar}} \mathrm{S}\right)(\AA)$ & $1.7746(17)$ & $1.796(7)-1.788(6)$ \\
\hline $\mathrm{d}-(\mathrm{S}-\mathrm{C})(\AA)$ & $1.817(2)$ & $1.793(11)-1.836(8)$ \\
\hline$\left(\mathrm{C}_{\mathrm{Ar}} \mathrm{S}(\mathrm{O})-\mathrm{C}\right)$ angle $\left(^{\circ}\right)$ & $99.98(9)$ & $98.3(3)-103.5(4)$ \\
\hline dihedral angle between & 12.92 & 51.43 \\
distal aryl rings $\left(^{\circ}\right)$ & & 49.23 \\
\hline $\mathrm{d}-(\mathrm{C} \equiv \mathrm{N})(\AA)$ & $1.142(3)$ & $1.134(11)-1.173(16)$ \\
\hline angle $(\mathrm{C}-\mathrm{C} \equiv \mathrm{N})\left(^{\circ}\right)$ & $178.8(3)$ & $172.0(18)-179.0(13)$ \\
\hline
\end{tabular}


Table 2: Crystallographic parameters recorded at $173 \mathrm{~K}$ for $\mathbf{2}, \mathbf{3}, \mathbf{2}-\mathbf{A g P F}_{\mathbf{6}}$ and $\mathbf{3}-\mathbf{A g P F}_{\mathbf{6}}$.

\begin{tabular}{|c|c|c|c|c|}
\hline Formula & $\begin{array}{c}2 \\
\mathrm{C}_{56} \mathrm{H}_{68} \mathrm{~N}_{4} \mathrm{~S}_{8}\end{array}$ & $\begin{array}{c}3 \\
\left(\mathrm{C}_{72} \mathrm{H}_{68} \mathrm{~N}_{4} \mathrm{~S}_{8}\right)_{2}, \mathrm{CH}_{2} \mathrm{Cl}_{2}\end{array}$ & 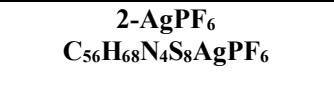 & $\begin{array}{c}3-\mathrm{AgPF}_{6} \\
\left(\mathrm{C}_{72} \mathrm{H}_{68} \mathrm{~N}_{4} \mathrm{~S}_{8}\right)_{4}\left(\mathrm{AgPF}_{6}\right)_{8}, 5 \\
\mathrm{CH}_{3} \mathrm{OH}, 2 \mathrm{CHCl}_{3}\end{array}$ \\
\hline Molecular weight & 1053.62 & 2576.49 & 1306.46 & 7528.90 \\
\hline Crystal system & Tetragonal & Triclinic & Monoclinic & Monoclinic \\
\hline Space group & $\mathrm{I} 4(1) / \mathrm{a}$ & $\mathrm{P}-1$ & $\mathrm{P} 2(1) / \mathrm{n}$ & $\mathrm{P} 2(1) / \mathrm{n}$ \\
\hline $\mathbf{a}(\AA)$ & $20.0614(3)$ & $15.0141(11)$ & $19.2889(8)$ & $19.4752(6)$ \\
\hline $\mathbf{b}(\AA)$ & $20.0614(3)$ & $15.5818(11)$ & $15.5560(6)$ & $25.5432(7)$ \\
\hline$c(\AA)$ & $14.4126(5)$ & $15.9100(10)$ & $20.8033(8)$ & $20.9692(6)$ \\
\hline$\alpha(\operatorname{deg})$ & 90 & $89.024(4)$ & 90 & 90 \\
\hline$\beta($ deg) & 90 & $80.624(4)$ & $100.485(2)$ & $114.2950(10)$ \\
\hline$\gamma(\operatorname{deg})$ & 90 & $72.540(3)$ & 90 & 90 \\
\hline $\mathbf{V}\left(\AA^{3}\right)$ & $5800.5(2)$ & $3501.2(4)$ & $6138.0(4)$ & $9507.5(5)$ \\
\hline $\mathbf{Z}$ & 4 & 1 & 4 & 1 \\
\hline Colour & Colorless & Colorless & Colorless & Colorless \\
\hline Crystal dim $\left(\mathrm{mm}^{3}\right)$ & $0.11 \times 0.10 \times 0.09$ & $0.10 \times 0.08 \times 0.06$ & $0.09 \times 0.06 \times 0.04$ & $0.08 \times 0.05 \times 0.04$ \\
\hline$D_{\text {calc }}\left(\mathrm{gcm}^{-3}\right)$ & 1.207 & 1.222 & 1.414 & 1.315 \\
\hline $\mathbf{F}(000)$ & 2240 & 1354 & 2704 & 3824 \\
\hline$\mu\left(\mathrm{mm}^{-1}\right)$ & 0.346 & 0.336 & 0.684 & 0.728 \\
\hline \multicolumn{5}{|l|}{ Wavelength $(\AA)$} \\
\hline Number of data meas. & 12356 & 32652 & 45319 & 210418 \\
\hline $\begin{array}{c}\text { Number of data with I> } \\
2_{\sigma(\mathrm{I})}\end{array}$ & $3305[\mathrm{R}(\mathrm{int})=0.0241]$ & $14865[\mathrm{R}(\mathrm{int})=0.0420]$ & $13951[\mathrm{R}(\mathrm{int})=0.0651]$ & $21897[\mathrm{R}$ (int) $=0.0454]$ \\
\hline $\mathbf{R}$ & $\mathrm{R} 1=0.0393, \mathrm{wR} 2=0.1115$ & $\mathrm{R} 1=0.1091, \mathrm{wR} 2=0.2691$ & $\mathrm{R} 1=0.0832, \mathrm{wR} 2=0.1843$ & $\mathrm{R} 1=0.1095, \mathrm{wR} 2=0.2525$ \\
\hline $\mathbf{R}_{\mathbf{W}}$ & $\mathrm{R} 1=0.0487, \mathrm{wR} 2=0.1236$ & $\mathrm{R} 1=0.1578, \mathrm{wR} 2=0.3803$ & $\mathrm{R} 1=0.1218, \mathrm{wR} 2=0.2060$ & $\mathrm{R} 1=0.1458, \mathrm{wR} 2=0.3055$ \\
\hline GOF & 0.996 & 1.400 & 1.113 & 1.579 \\
\hline $\begin{array}{c}\text { Largest diff. peak and } \\
\text { hole (e.Å-3) }\end{array}$ & 0.617 and -0.404 & 1.208 and -1.176 & 1.535 and -0.872 & 3.281 and -1.755 \\
\hline
\end{tabular}


Generation of 1D and 3D silver coordination networks formed upon combinations of tectons $\mathbf{1}$ and $\mathbf{2}$ respectively with $\mathrm{AgPF}_{6}$ salt. A.S. Ovsyannikov, S. Ferlay, S. E. Solovieva, I. S. Antipin, A. I. Konovalov, N. Kyritsakas and M. W. Hosseini

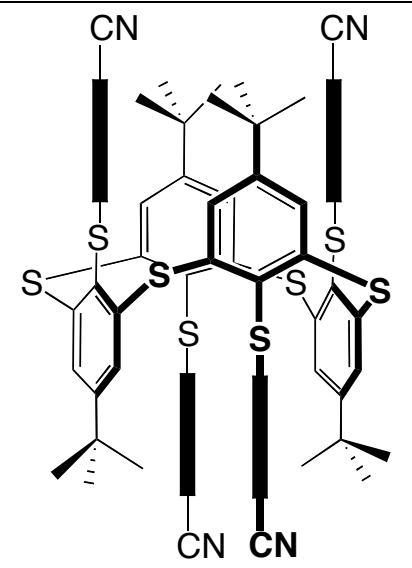

